\section{Investigation of Bacterial Contents From Persistent Endodontic Infection and Evaluation of Their Inflammatory Potential}

Flávia Goulart da Rosa Cardoso ${ }^{1,2}$, Adriana Chung ${ }^{1}$, Frederico Canato Martinho ${ }^{1}$, Carlos Henrique Ribeiro Camargo ${ }^{1}$, Claudio Antônio Talge Carvalho ${ }^{1}$, Brenda Paula Figueiredo de Almeida Gomes ${ }^{3}$, Marcia Carneiro Valera $^{1}$

This clinical study investigated and quantified cultivable bacteria and their levels of endotoxins in persistent endodontic infection, determining their antigenicity against macrophages and fibroblast cells by IL-1 $\beta$ and TNF- $\alpha$ secretion and evaluating their relationship with clinical and radiographic features. Samples from the root canals were obtained after root filling removal. Culture techniques were used to determine the bacterial count and the endotoxins were determined by LAL-assay. PCR analysis (16S rDNA) was used for bacterial detection. Raw 264.5 macrophages and V79 fibroblast were stimulated with endodontic contents. ELISA assay measured the amounts of IL-1B/TNF- $\square$ secretion. Bacteria and endotoxin medians were $1.24 \times 10^{5} \mathrm{CFU} / \mathrm{mL}$ and $9.62 \mathrm{EU} / \mathrm{mL}$, respectively. Porphyromonas endodontalis was the most frequently detected species. Higher levels of endotoxins were found in teeth with pain on palpation $(23.56 \mathrm{EU} / \mathrm{mL})$ rather than in its absence $(8.21 \mathrm{EU} / \mathrm{mL})$. Larger areas of bone destruction were related to higher levels of endotoxins and IL- $1 \beta$ and TNF- $\alpha$ secretion. The study findings revealed the presence of Gram-negative bacteria species in persistent endodontic infection, with their endotoxins related to both severity of bone destruction and development of symptomatology. Moreover, larger areas of bone destruction were related to higher levels of IL-1 $\beta$ and TNF- $\alpha$ secreted by macrophages and fibroblast cells.

\author{
'Department of Restorative Dentistry, \\ Endodontic Division, Institute of \\ Science and Technology, UNESP \\ - Univ Estadual Paulista, São \\ José dos Campos, SP, Brazil \\ ${ }^{2}$ Department of Odontology, \\ Endodontic Division, UNITAU \\ - Universidade de Taubaté, \\ Taubaté, SP, Brazil \\ ${ }^{3}$ Department of Restorative \\ Dentistry, Endodontic Division, \\ Piracicaba Dental School, UNICAMP \\ - Universidade Estadual de \\ Campinas, Piracicaba, SP, Brazil
}

Correspondence: Profa. Dra. Marcia Carneiro Valera, Avenida Eng. Francisco José Longo, 777, Jd. São Dlmas, 12245-000 São José dos Campos, SP, Brasil. Tel: +55-12-39479400 e-mail: marcia@fosjc.unesp.br

Key Words: bacteria, cytokines, endodontic infection, endotoxin, root canals.

\section{Introduction}

Previous studies from root-filled teeth with apical periodontitis have revealed a microbiota comprised predominantly by Gram-positive bacterial species $(1,2)$. However, with the advances in molecular techniques, including polymerase chain reaction (PCR) and sequencing analyzes, it has been revealed a far more complex microbiota in teeth with endodontic failure, with involvement of different Gram-negative anaerobic bacterial species $(2,3)$. Among the Gram-negative anaerobic bacterial species, Porphyromonas, Prevotella, Fusobacterium, Tanerella and Treponema are the most frequently detected ones $(2,4)$. These species possess lipopolysaccharides (LPS), also known as endotoxin, a constituent of the cell wall (5) exerting a potent biological inflammatory reaction (6). In root canal infections, endotoxins may trigger pain because of their roles in releasing vasoactive substances and neurotransmitters in the periapical tissues near nerve endings (7).

Endotoxin is one of the most important virulent factors involved in the development of periapical inflammation (5, 8), which interacts with monocytes, macrophages, and other cells of the immune systems and fibroblasts, leading to the production of pro-inflammatory cytokines, such as IL-1 $\beta$ and TNF- $\alpha(8,9)$. Previous studies focused on the analysis of endotoxins in primary root canal infection correlating their levels with the presence of clinical signs/symptoms (10-12). Martinho et al. (9) reported that the high antigenic activity of bacterial endodontic contents from primary root canal infection was a potent stimuli against macrophages in the release of IL- $1 \beta$ and TNF- $\alpha$, demonstrating a positive correlation between levels of endotoxins present in root canals and production of IL- $1 \beta$ and TNF- $\alpha$. However, little is known about endotoxins in persistent endodontic infection $(2,11,13)$ and their role in the development of clinical symptomatology and periapical bone destruction.

Overall, this clinical study investigated and quantified cultivable bacteria and their levels of endotoxins found in persistent endodontic infection, determining their antigenicity against macrophages and fibroblast cells through IL-1 $\beta$ and TNF- $\alpha$ secretion and evaluating their relationship with clinical and radiographic features.

\section{Material and Methods} Case Selection

This study was previously approved by the Research and 
Ethics Committee of UNESP - São Paulo State University, São José dos Campos, Brazil. Ten patients attending the Dental Clinics of the São Paulo State University (UNESP), São José dos Campos (SP), Brazil, for endodontic retreatment were included in the present study. A detailed medical and dental history was obtained for each patient. The failure of root canal treatment was determined on the basis of clinical and radiographic examinations. The presence of persistent or emergent periapical radiolucent lesion, quality of the root canal filling (the density of the filling indicating the quality of condensation- Homogeneous: good condensation with no voids visible and Inhomogeneous root filling: poor condensation with voids visible; the distance between the end of the filling material and radiographic apex acceptable root filling terminating: $0-1 \mathrm{~mm}$ from the radiographic apex and unacceptable - root filling extending beyond), persistent or emergent symptoms (e.g. pain on palpation, tenderness to percussion), and persistent sinus tract were considered reasons for retreatment. Patients who had received antibiotic treatment within the prior 3 months and teeth that had periodontal pockets deeper than $4 \mathrm{~mm}$ were excluded.

The following clinical/radiographic features were recorded for each patient: time after endodontic treatment, tenderness to percussion (TTP), pain on palpation (POP), presence or absence of sound coronal restoration, caries, sinus tract, radiographic quality of the root canal filling, and size of periapical lesion (size of bone destruction). For the measurement of the size of radiolucent area, the images were digitalized and transferred to the Image J software (version $1.28 \mathrm{u}$, National Institutes of Health, Washington, DC, USA) and the larger border distance in $\mathrm{mm}$ were recorded. All these could be correlated with microbial endotoxin and levels of pro-inflammatory (IL-1 $\beta$ and TNF- $\alpha$ ) secreted by macrophages and fibroblast cells.

\section{Sampling Procedures}

Files, instruments, and all materials used in this study were treated with $\mathrm{C}^{60}$ gamma radiation ( $20 \mathrm{kGy}$ for 6 hours) for sterilization and elimination of preexisting endotoxins (14) (EMBRARAD; Empresa Brasileira de Radiação, Cotia, SP, Brazil). The method used for disinfection of the operative field was previously described elsewhere $(9,11)$. Sterility of the external surfaces of the crown was checked by taking a swab sample from the crown surface and streaking it onto blood agar plates, which were then incubated both aerobically and anaerobically.

Each patient received local anesthesia around each individual tooth to be isolated from the oral cavity with rubber dam, and disinfection of the external surfaces and surrounding areas was carried out by using $30 \%$ hydrogen peroxide solution (Byofórmula, São José dos Campos, SP,
Brazil) followed by sodium hypochlorite solution 5.25\% (Byofórmula, São José dos Campos, SP, Brazil). The solutions were inactivated with $5 \%$ sodium thiosulfate to avoid interference with the bacteriologic sampling.

A two-stage access cavity preparation was made without the use of water spray, but under manual irrigation with sterile/apyrogenic saline solution and by using sterile/ apyrogenic high-speed diamond bur. The first stage was performed to promote a major removal of contaminants, including carious lesion and restoration. In the second stage, before entering the root canal, the access cavity was disinfected according to the protocol described above. After preparing the access cavity, the root filling was removed by using Gates-Glidden drills (Dentsply/Maillefer Instruments SA, Ballaigues, Switzerland) and endodontic files (Dentsply/ Maillefer Instruments SA, Ballaigues, Switzerland) without any solvent for gutta-percha. The canal was then inundated with pyrogen-free saline solution before the root canal sampling.

Four pyrogen-free paper points (Dentsply Maillefer Ind. E Com. Ltda, Petrópolis, Brazil) were sequentially placed into the full length of the canal (as determined by a preoperative radiograph) and kept in place for $60 \mathrm{~s}$. The first paper point was immediately transferred to a test tube containing 1 $\mathrm{mL}$ LAL-free-endotoxin water (Lonza, Walkersville, MD) for endotoxin analysis and the other three paper points were pooled in a sterile tube containing $1 \mathrm{~mL}$ of VMGA III (15, 16) for bacterial analysis. The transport medium samples were transferred to anaerobic jars within 15 minutes for bacterial analysis.

\section{Bacterial Culture Procedure - Bacterial counts (CFU) $m L)$}

The tubes holding the transport medium samples were shaken thoroughly in a mixer for $60 \mathrm{~s}$. Serial 10fold dilutions were made up to $10^{-4}$ in tubes containing fastidious anaerobe broth ( $F A B, L A B M, B u r y, U K)$. Fifty microliters of each serial dilution were plated onto $5 \%$ defibrinated sheep blood fastidious anaerobe agar (FAA; LAB M) by using sterile plastic spreaders to culture nonselectively obligate and facultative anaerobes. The plates were incubated at $37{ }^{\circ} \mathrm{C}$ in an anaerobic atmosphere of $10 \% \mathrm{H}_{2}, 10 \% \mathrm{CO}_{2}$ and $80 \% \mathrm{~N}_{2}$ for up to 14 days. After this period, the colony-forming units (CFUs) were visually quantified for each plate.

\section{PCR Analysis (16S rDNA) - Investigation of Selected Bacterial Species}

Polymerase chain reaction (PCR) was used to detect Filifactor alocis, Porphyromonas endodontalis, Porphyromonas gingivalis, Prevotella intermedia, Prevotella nigrescens, Tannerella forsythia and Treponema 
denticola. The reference bacterial strains used in this study were purchased from the American Type Culture Collection (ATCC) and listed as follows: Filifactor alocis (ATCC 35896), Porphyromonas endodontalis (ATCC 35406), Porphyromonas gingivalis (ATCC 33277), Prevotella intermedia (ATCC 25611), Prevotella nigrescens (ATCC 33099), Tannerella forsythia (ATCC 43037) and Treponema denticola (ATCC 35405). Species-specific primers targeting the $16 \mathrm{~S}$ rDNA coding region in each bacterial genome were used. The oligonucleotide sequences are shown in Table 1.

DNA extraction - microbial DNA from initial endodontic samples as well as from ATCC bacterial strains were extracted and purified by the OIAamp DNA Kit (Qiagen, Chatsworth, CA, USA) and amplified by using prokaryotic $16 \mathrm{~S}$ ribosomal DNA-targeted primers. The final PCR product represented the $16 \mathrm{~S}$ rDNA and its inner regions.

PCR assay - The PCR mixture had a final volume of 25 $\mu \mathrm{L}$. The PCR master mix contained $1.5 \mu \mathrm{L}$ of sample DNA, 18.6 $\mu$ L ultra-pure $\mathrm{H}_{2} \mathrm{O}$ (Milli-Q, Invitrogen ${ }^{\circledR}$, São Paulo, SP, Brazil), $2.5 \mu \mathrm{L}$ buffer (10x Reaction Buffer, Invitrogen ${ }^{\circledR}$ ), $1.25 \mu \mathrm{L} \mathrm{MgCl}_{2}$ (Invitrogen ${ }^{\circledR}$ ), $0.125 \mu \mathrm{L}$ Platinum Taq DNA polymerase (Invitrogen $\left.{ }^{\circledR}\right), 0.5 \mu \mathrm{L}$ dNTPs (Invitrogen $\left.{ }^{\circledR}\right), 0.25$ - $\mu \mathrm{L}$ Forward Primer (Invitrogen ${ }^{\circledR}$ ) and $0.25 \mu \mathrm{L}$ Reverse Primer (Invitrogen ${ }^{\circledR}$ ). The annealing temperature was determined with a varying temperature gradient through several PCRs by using combinations of the species-specific primers. The reactions were performed in a conventional thermal cycler - (Gene Pro Thermal Cycler, BIOER Technology, Hangzhou, China). Samples containing genomic DNA purified from American Type Culture Collection (ATCC) species were used as positive controls. In the negative control, the DNA volume was replaced by Milli- 0 water.

Amplified samples were analyzed with 1\% agarose gel electrophoresis (Invitrogen ${ }^{\circledR}$ ). The gel was stained with ethidium bromide $(5 \mu \mathrm{g} / \mathrm{mL})$ (Invitrogen $\left.{ }^{\circledR}\right)$ and a $100 \mathrm{bp}$ DNA ladder (Invitrogen ${ }^{\circledR}$ ) was used as standard for each reaction. The DNA bands were visualized under UV light, and the gel was photographed with an Image Master System VDS (Pharmacia Biotech, Cambridge, UK). Images of the gels were processed by the LISCAP image capture software.

\section{LAL assay (KOCL test) - Quantification of Endotoxins}

The kinetic chromogenic limulus amebocyte lysate (LAL) (Lonza, Walkersville, MD, USA) assay was used for quantification of endotoxins. Escherichia coli endotoxin was the standard. A positive control (root canal sample contaminated with a known amount of endotoxin) was included for each sample to determine the presence or absence of interfering agents. For the test, $100 \mu \mathrm{L}$ of apyrogenic water (reaction blank), 5 standard endotoxin solutions [0.005-50 endotoxin units $(\mathrm{EU}) / \mathrm{mL}]$, root canal samples and positive controls were added to a 96-well apyrogenic plate. The tests were carried out in quadruplicate. The plate was incubated at $37 \pm 1{ }^{\circ} \mathrm{C}$ for $10 \mathrm{~min}$ in the Kinetic-OCL reader, which was coupled to a microcomputer with the WinKOCL software. Next, $100 \mu \mathrm{L}$ of the chromogenic reagent was added to each well. After the beginning of the kinetic test, the software monitored continuously the absorbance at $405 \mathrm{~nm}$ in each microplate well and automatically calculated the $\log / \log$ linear correlation between reaction time of each standard and the corresponding endotoxin concentration.
Table 1. Polymerase chain reaction primer pairs used for the detection of target Gramnegative bacterial species in teeth with secondary/ persistent endodontic infection

\begin{tabular}{|c|c|c|}
\hline Target & Primer Pair & $\begin{array}{l}\text { Amplicon } \\
\text { Length (bp) }\end{array}$ \\
\hline Universal & $\begin{array}{c}\text { F: TCC TAC GGG AGG CAG CAG T } \\
\text { R: GGA CTA CCA GGG TAT CTA ATC CTG TT }\end{array}$ & $466 \mathrm{bp}$ \\
\hline P. endodontalis & $\begin{array}{l}\text { F: GCT GCA GCT CAA CTG TAG TC } \\
\text { R: CCG CTT CAT GTC ACC ATG TC }\end{array}$ & $672 \mathrm{bp}$ \\
\hline P. gingivalis & $\begin{array}{l}\text { F: AGG CAG CTT GCC ATA CTG CG } \\
\text { R: ACT GTT AGC AAC TAC CGA TGT }\end{array}$ & $404 \mathrm{bp}$ \\
\hline P. intermedia & $\begin{array}{l}\text { F: TTT GTT GGG GAG TAA AGC GGG } \\
\text { R: TCA ACA TCT CTG TAT CCT GCG T }\end{array}$ & $575 \mathrm{bp}$ \\
\hline P. nigrescens & $\begin{array}{l}\text { F: ATG AAA CAA AGG TTT TCC GGT AAG } \\
\text { R: CCC ACG TCT CTG TGG GCT GCG A }\end{array}$ & 804 bp \\
\hline T. forsythia & $\begin{array}{l}\text { F: GCG TAT GTA ACC TGC CCG CA } \\
\text { R: TGC TTC AGT GTC AGT TAT ACC T }\end{array}$ & $641 \mathrm{bp}$ \\
\hline T. denticola & $\begin{array}{l}\text { F: TAA TAC CGA ATG TGC TCA TTT ACA T } \\
\text { R: TCA AAG AAG CAT TCC CTC TTC TTA }\end{array}$ & $316 \mathrm{bp}$ \\
\hline F. alocis & $\begin{array}{l}\text { F: CAG GTG GTT TAA CAA GTT AGT GG } \\
\text { R: CTA AGT TGT CCT TAG CTG TCT CG }\end{array}$ & $594 \mathrm{bp}$ \\
\hline
\end{tabular}

Raw 264.5 Macrophages and V79 Fibroblast Culture - Cell Stimulation with Endodontic Contents

Macrophages (RAW 264.7) and fibroblasts (V79) were cultured in 100-mm plates containing Dulbecco's modified Eagle's minimal essential medium (DMEM) supplemented with $100 \mathrm{IU} / \mathrm{mL}$ of penicillin, $100 \mathrm{Dg} / \mathrm{mL}$ of streptomycin and 10\% heat-inactivated fetal bovine serum and maintained in a humidified atmosphere at $37{ }^{\circ} \mathrm{C}$ and $5 \%$ $\mathrm{CO}_{2}$ until $90 \%$ confluence. Unless noted otherwise, all tissue culture reagents were purchased from Invitrogen (Carlsbad, CA, USA). Macrophages were released from $100-\mathrm{mm}$ plates with $0.25 \%$ trypsin, counted in a Newbauer chamber and $10^{4}$ macrophages were grown for $48 \mathrm{~h}$ in each well of six-well plates, de-induced by 
incubation for $8 \mathrm{~h}$ in culture medium (DMEM) containing $0.3 \%$ fetal bovine serum and stimulated with $60 \mu \mathrm{L}$ of root canal contents during $24 \mathrm{~h}$ in order to quantify the total amount of proteins released in the culture media (i.e. IL-1B and TNF- $\square$ ). The supernatants were collected and stored at $-80{ }^{\circ} \mathrm{C}$ until protein evaluation.

The amounts of IL- $1 B$ and TNF- $\square$ released to the culture media following stimulation of the root canal contents were measured by enzyme-linked immunosorbent assay - Duoset kit (ELISA; R\&D, Minneapolis, MN, USA). Next, a standard or sample solution was added to ELISA well plate, pre-coated with specific monoclonal capture antibody. After being gently shaken for $3 \mathrm{~h}$ at room temperature, the polyclonal anti-TNF- $\square$ and IL-1 13 antibodies, conjugated with horseradish peroxidase, were added to the solution and incubated for $1 \mathrm{~h}$ at room temperature. The substrate solution containing hydrogen peroxidase and chromogen was added and allowed to react for $20 \mathrm{~min}$. The levels of cytokines were assessed by a microelisa reader (R\&D) at 450 $\mathrm{nm}$ and normalized with abundance of standard solution. Each densitometric value, expressed as mean $\pm S D$, was obtained from three independent experiments.

\section{Statistical Analysis}

The data collected for each case (clinical features and bacteria isolated) were entered onto a spreadsheet and statistically analyzed by using the SPSS for Windows (SPSS, Inc., Chicago, IL, USA). Either Pearson's chi-square test or one-sided Fisher's exact test was chosen as appropriate to test the null hypothesis between the number of different bacterial species and the presence of clinical and radiographic features. Pearson's correlation coefficient was used to correlate the amount of LPS and IL- $1 \beta$ and TNF- $\alpha$ levels each two at a time. Association between presence or absence of clinical features and size of radiographic findings with the levels of LPS, IL-1 $\beta$ and TNF- $\alpha$ was analyzed by using the one-way ANOVA test. $\mathrm{P}<0.05$ was considered statistically significant.

\section{Results}

Sterility samples taken from the external and internal surfaces of the crown and their surrounding structures, tested before and after entering the pulp chamber, showed no microbial growth. The following clinical/radiographic features were found in root canals with persistent endodontic infections investigated: pain on palpation (POP) $(2 / 10)$, tenderness to percussion (TTP) $(6 / 10)$, size of radiolucent area $\leq 5 \mathrm{~mm}(5 / 10)$ and $\geq 6 \mathrm{~mm}(5 / 10)$, acceptable root filling terminating and homogenous filling $(5 / 10)$, and time of previous treatment $\leq 5$ years $(6 / 10)$ and $\geq 6$ years $(4 / 10)$.

Cultivable bacteria were detected in $100 \%$ of the root canal samples (10/10), with a median value of $1.24 \times 10^{5} \mathrm{CFU} / \mathrm{mL}$. Bacterial DNA was detected in 10/10 root canal samples with persistent endodontic infections as determined by using ubiquitous bacterial primers. No positive results were observed for presence of bacterial DNA in negative control samples. At least one Gramnegative bacterial species was detected in $60 \%$ of the root canal samples (6/10). A combination of two or more Gram-negative target species was detected in 30\% of the root canals (3/10), with Porphyromonas endodontalis (5/10), Tanerella forsythia (3/10), Porphyromonas gingivalis (1/10), Treponema denticola $(1 / 10)$ being detected in the root canals, respectively.

The standard curve for detection of endotoxins fulfilled the criteria of linearity $(r=1)$. The kinetic chromogenic LAL assay revealed that endotoxins were present in 100\% of the root canal samples (10/10), with a median value of $9.62 \mathrm{EU} / \mathrm{mL}$ (ranging from 2.26 to $31.3 \mathrm{EU} / \mathrm{mL}$ ). Higher levels of endotoxins were found in teeth with pain on palpation (POP) (median value: $23.56 \mathrm{EU} / \mathrm{mL}$ ) than in their absence (median value: $8.21 \mathrm{EU} / \mathrm{mL})(p<0.05)$. Teeth with larger area of bone destruction showed higher values of endotoxin (median value of $11.1 \mathrm{EU} / \mathrm{mL}$ for areas $\leq 5 \mathrm{~mm}$ vs median value of $3.91 \mathrm{EU} / \mathrm{mL}$ for areas $\geq 6 \mathrm{~mm})(p<0.05)$. Higher levels of IL- $1 \beta$ and TNF- $\alpha$ secreted by macrophages and fibroblast cells $(p<0.05)$ were related to a larger size of radiolucent area $(\geq 6 \mathrm{~mm}$ ) (Fig. 1).

\section{Discussion}

Analyses of the results indicated that bacteria were recovered from persistent endodontic infection at significant levels, with involvement of selected Gramnegative bacterial species, particularly Porphyromonas endodontalis and Tanerella forsythia. Moreover, higher levels of endotoxins in root-filled teeth were related to the presence of clinical symptoms and larger area of bone destruction. Thus, larger area of bone destruction was related to higher levels of IL- $1 \beta$ and TNF- $\alpha$ secreted by macrophages and fibroblast cells.

In the present study, cultivable bacteria were detected in all root canal samples of teeth with persistent infection. However, there is controversy on the origin of this type of infection, whether it results from the persistent primary infection located in strategic areas not reached by instrumentation or from new infection of the root canal systems by coronal leakage (secondary infection). Regardless of that, there is a consensus that the need for a new endodontic treatment involves the elimination of apical periodontitis. The number of viable bacterial counts found in root canals with secondary/persistent infection was $10^{5} \mathrm{CFU} / \mathrm{mL}$. Cheung and $\mathrm{Ho}$ (17) demonstrated values of CFU-counts ranging from 40 to $7 \times 10^{7}$. Corroborating 
this finding, Endo et al. (2) reported an initial number of viable bacteria in post-treatment apical periodontitis ranging from 0 to $2.3 \times 10^{5} \mathrm{CFU} / \mathrm{mL}$.

Corroborating with the culture analysis, bacterial DNA was found in 10 out of 10 root canal samples determined by ubiquitous bacterial primers. The PCR-analysis revealed that at least one of the seven target Gram-negative bacterial species was detected in $60 \%$ of the root canal samples. Furthermore, a combination of two or more Gram-negative target species was detected in 30\% of the investigated root canals, indicating that different bacterial LPS with different toxicity structure (lipid A) (18) could be involved in the persistent infection, which enhances or even inhibits each other's antigenicity to the periradicular tissue, making bacterial endodontic contents even more complex to the innate response (9). This finding is in agreement with previous pyrosequencing studies $(3,19)$ revealing far more diverse and complex community profiles in persistent infection than previously described by culture and molecular studies (4).

Among the target Gram-negative bacterial species investigated in the present study, Porphyromonas endodontalis (50\%) and Tanerella forsythia (30\%) were the most frequently recovered species from teeth with secondary/persistent infection. Siqueira and Rôças (20) detected T. forsythia in 23\% and $P$. endodontalis in only $5 \%$ of their samples. In contrast, Zhang et al. (21) found $P$. endodontalis in $45 \%$ of their samples. Such variations can be attributed to the case selection, particularly regarding the presence or absence of clinical/radiographic features. In the current study, from the bacterial selection, $P$. endodontalis was the most frequently detected species in teeth with persistent endodontic infection and apical periodontitis. The high frequency of $P$. endodontalis in endodontic infections has been attributed to the presence of periapical bone destruction $(8,22)$. Thus, $P$. endodontalis

\section{A}

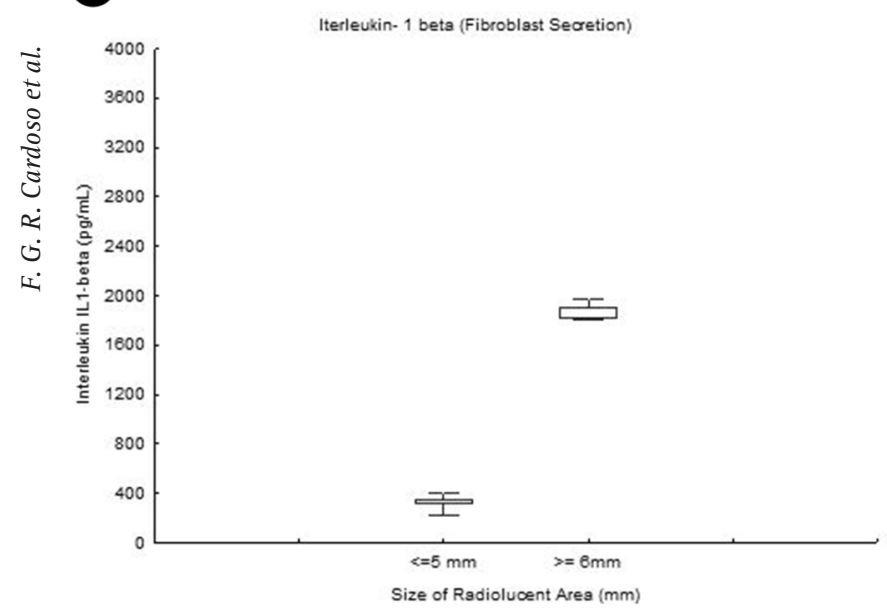

C

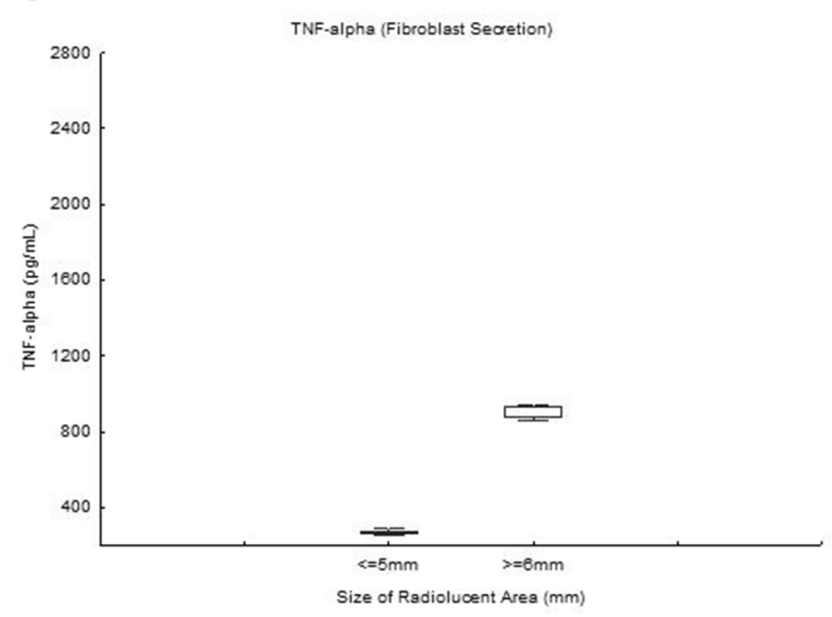

B

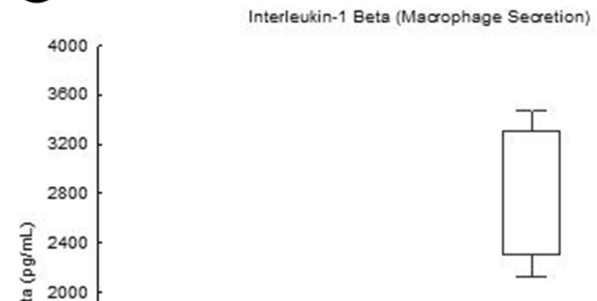

$\stackrel{\Xi}{\stackrel{\Xi}{\Xi}}$

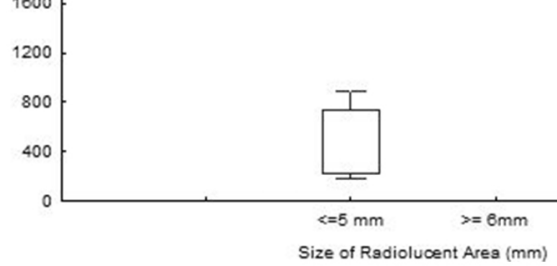

D

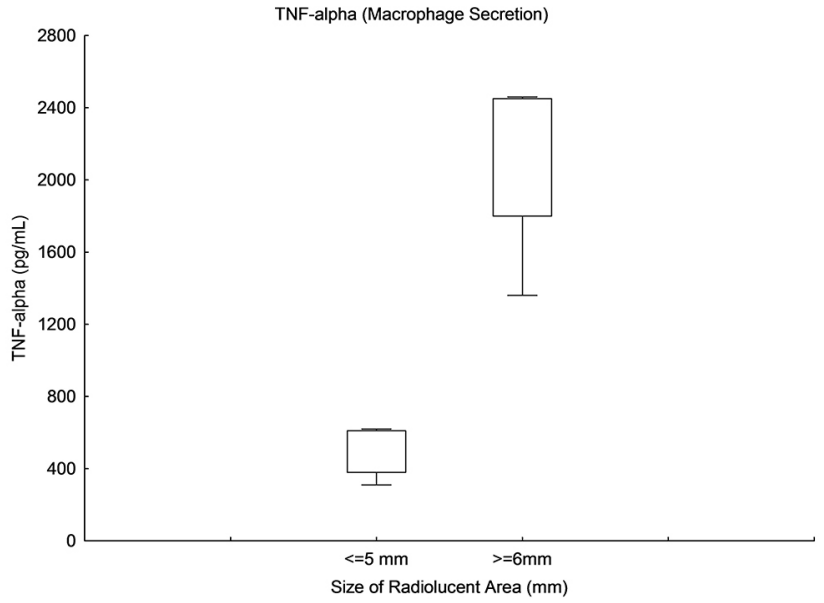

Figure 1. Median levels of IL-1 beta and TNF-alpha secreted by macrophage and fibroblast cells after stimulation with secondary/ persistent endodontic contents. 
was frequently recovered from root canals with secondary/ persistent infection concomitant with at least one other target Gram-negative bacterial species. It is worth to point out that, although experimental mono-infections by $P$. endodontalis have shown a relatively low pathogenicity, mixed culture containing this species has been shown to cause severe infection (22).

Endotoxin was recovered from all root canal samples collected from secondary/persistent infection, corroborating previous studies $(2,11)$. The kinetic chromogenic LAL assay (KOCL test) used in the present study demonstrated to be effective in the recovery of endotoxins from secondaryl persistent endodontic infection, showing a median value of $9.62 \mathrm{EU} / \mathrm{mL}$. Endo et al. (2) using the kinetic turbidimetric LAL assay (Pyrogent 5000), investigated the presence of endotoxins in secondary/persistent endodontic infections and reported a $3.96 \mathrm{EU} / \mathrm{mL}$ median value of endotoxins . The differences in endotoxin measurements between these two studies may be ascribed to the different methods used by the authors. These two kinetic methods present different test principles (use of chromogenic synthetic LAL substrate in the KOCL vs. native substrate [coagulogen] in the turbidimetric method). Regardless of this, Martinho et al. (23) reported that these two LAL methods are the best fit ones for the analysis of endotoxins in root canal infections. It is not unreasonable to assume that such differences may also be attributed to case selection.

Although target Gram-negative bacterial species were detected in only 6/10 root canals investigated, endotoxin was recovered from all the analyzed 10 teeth. Such a result possibly indicates that the endotoxins detected in these root canals can be either from other Gram-negative bacteria not included in the present study or even from other bacterial species present in root canals at low DNA concentration, thus being undetected by PCR 165 rDNA assay. It is noteworthy that a single Gram-negative bacterial cell contains $\approx 10^{6}$ lipid A residues (the LPS domain responsible for its toxicity).

Higher median levels of endotoxins have been currently found in teeth with pain on palpation (23.56 EU/mL) rather than in its absence $(8.21 \mathrm{EU} / \mathrm{mL})$. This finding was corroborated by Horiba et al. (13), who reported a positive correlation between higher detection rates of endotoxins and symptomatic teeth with post-treatment apical periodontitis. Gomes et al. (11) also revealed a correlation between higher levels of endotoxins found in teeth with persistent infections and presence of clinical symptoms.

With respect to bone destruction in apical periodontitis, higher levels of endotoxins were detected in teeth presenting larger area of bone destruction $[\geq 6 \mathrm{~mm}(11.1$ $\mathrm{EU} / \mathrm{mL})]$, whereas significantly lower levels were observed in periapical lesions with smaller radiolucent areas $[\leq 5 \mathrm{~mm}$
(3.91 EU/mL)], thus elucidating the role of endotoxins in the bone resorption in apical periodontitis (9). Typical result was also shown by Schein and Schilder (5) and Horiba et al. (13).

Previous in vitro studies have demonstrated that oral bacterial LPSs are potent stimuli for pro-inflammatory cytokines involved in periapical tissue destruction $(4,16,17)$. However, a limited clinical conclusion can be drawn from these studies as they attempted to extract LPS from a single bacterial species and determine individually the LPS antigenicity $(3,13)$. However the present study was aimed to better reproduce the complexity of endodontic infection contents by considering the "whole pool of infections" sampled straight from the infection as it actually is.

Even at low amounts, endotoxins are extremely strong stimulators of inflammatory reactions, particularly the production of IL-1 $\beta$ and TNF- $\alpha$ (8-10). In the present study, not only higher levels of endotoxins were detected in teeth with larger area of bone destruction, but also higher levels of IL- $1 \beta$ and TNF- $\alpha$ secreted by macrophages and fibroblast cells were found to be related to this radiographic feature. These findings agree with Pezelj-Ribarić et al. (24) who reported the recovery of higher levels of TNF- $\alpha$ in teeth with larger apical periodontitis. Highlighting, TNF- $\alpha$ leads to bone resorption by osteoclast activation and stimulated secretion of proteolytic enzymes, plasminogen activator (PA) and matrix metalloproteinases (MMP), which are in charge of destroying extracellular matrix bone tissue (25).

Overall, the present findings revealed the presence of Gram-negative bacterial species in persistent endodontic infection, with their endotoxin levels related to both severity of bone destruction and development of clinical symptoms. Moreover, a larger area of bone destruction was associated with higher levels of IL- $1 \beta$ and TNF- $\alpha$ secreted by macrophages and fibroblast cells commonly encountered in periapical tissue.

\section{Resumo}

Este estudo clínico investigou e quantificou bactérias cultiváveis e seus níveis de endotoxinas na infecção endodôntica persistente, determinando a sua antigenicidade contra macrófagos e células de fibroblastos através de IL-1 $\beta$ e TNF- $\alpha$; e avaliando sua relação com características clínicas e radiográficas. As amostras dos canais radiculares foram obtidas após a desobturação. Técnicas de cultura foram utilizadas para determinar a contagem de bactérias e a quantificação de endotoxinas foram determinadas por ensaio de LAL. Análise por PCR (16S rDNA) foi utilizada para a detecção bacteriana. Células 264,5 macrófagos e fibroblastos V79 foram estimuladas com conteúdo endodôntico. IL-1 $\beta$ e TNF- $\alpha$ produzidas pelas células avaliadas foram medidas por ensaio de ELISA. As medianas de bactérias e endotoxinas foram 1,24x105 UFC/mL e 9,62 $\mathrm{EU} / \mathrm{mL}$, respectivamente. Porphyromonas endodontalis foi a espécie mais frequentemente detectada. Níveis mais elevados de endotoxinas foram encontrados em dentes com dor à palpação $(23,56 \mathrm{EU} / \mathrm{mL})$ quando comparado a sua ausência $(8,21 \mathrm{EU} / \mathrm{mL})$. Maiores áreas de destruição óssea foram relacionados com níveis mais elevados de endotoxinas e IL-1 $\beta$ e TNF- $\alpha$. 0 estudo revelou presença de espécies de bactérias Gramnegativas em infecção endodôntica persistente, com níveis elevados de 
endotoxinas relacionados a maior destruição óssea periapical e presença de sintomatologia. Além disso, grandes áreas de destruição óssea foram relacionados com niveis mais elevados de IL- $1 \beta$ e TNF- $\alpha$ secretadas por macrófagos e fibroblastos.

\section{References}

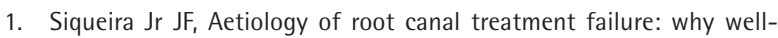
treated teeth can fail. Int Endod J 2001;34:1-10.

2. Endo MS, Martinho FC, Zaia AA, Ferraz CC, Almeida JF, Gomes BP. Quantification of cultivable bacteria and endotoxin in post-treatment apical periodontitis before and after chemo-mechanical preparation. Eur J Clin Microbiol Infect Dis 2012;31:2575-2583.

3. Hong BY, Lee TK, Lim SM, Chang SW, Park J, Han SH, et al.. Microbial analysis in primary and persistent endodontic infections by using pyrosequencing. J Endod 2013;39:1136-1140.

4. Gomes BP, Pinheiro ET, Jacinto RC, Zaia AA, Ferraz CC, Souza-Filho FJ. Microbial analysis of canals of root-filled teeth with periapical lesions using polymerase chain reaction. J Endod 2008;34:537-540.

5. Schein B, Schilder H. Endotoxin content in endodontically involved teeth. J Endod 1975;1:19-21.

6. Barthel $C R$, Levin LG, Reisner HM, Trope M. TNF-alpha release in monocytes after exposure to calcium hydroxide treated Escherichia coli LPS. Int Endod J 1994;30:155-159.

7. Seltzer S, Farber PA. Microbiologic factors in endodontology. Oral Surg Oral Med Oral Pathol 1994;78:634-645.

8. Hong $\mathrm{CY}$, Lin SK, Kok SH, Cheng SJ, Lee MS, Wang TM, et al.. The role of lipopolysaccharide in infectious bone resorption of periapical lesion. J Oral Pathol Med 2004;33:162-169.

9. Martinho FC, Chiesa WM, Leite FR, Cirelli JA, Gomes BP. Antigenic activity of bacterial endodontic contents from primary root canal infection with periapical lesions against macrophage in the release of interleukin-1beta and tumor necrosis factor alpha. J Endod 2010;36:1467-1474.

10. Oliveira LD, Carvalho CA, Carvalho AS, Alves JS, Valera MC, Jorge A0. Efficacy of endodontic treatment for endotoxin reduction in primarily infected root canals and evaluation of cytotoxic effects. J Endod 2012;38:1053-1057.

11. Gomes BP, Endo MS, Martinho FC. Comparison of endotoxin levels found in primary and secondary endodontic infections. J Endod 2012;38:1082-1086.

12. Martinho FC, Chiesa WM, Leite FR, Cirelli JA, Gomes BP. Antigenicity of primary endodontic infection against macrophages by the levels of PGE(2) production. J Endod 2011;37:602-607.

13. Horiba $N$, Maekawa $Y$, Abe $Y$, Ito $M$, Matsumoto $T$, Nakamura $H$. Correlations between endotoxin and clinical symptoms or radiolucent areas in infected root canals. Oral Surg Oral Med Oral Pathol 1991;71:492-495.
14. Csako G, Elin RJ, Hochstein HD, Tsai CM. Physical and biological properties of U.S. standard endotoxin EC after exposure to ionizing radiation. Infect Immun 1983;41:190-196.

15. Möller AJ, Fabricius L, Dahlén G, Ohman AE, Heyden G. Influence on periapical tissues of indigenous oral bacteria and necrotic pulp tissue in monkeys. Scand J Dent Res 1981;89:475-484.

16. Dahlén G, Pipattanagovit $P$, Rosling B, Möller AJ. A comparison of two transport media for saliva and sub gingival samples. Oral Microbiol Immunol 1993;8:375-382.

17. Cheung GS, Ho MW. Microbial flora of root canal-treated teeth associated with asymptomatic periapical radiolucent lesions. Oral Microbiol Immunol 2001;16:332-337.

18. Dixon DR, Darveau RP. Lipopolysaccharide heterogeneity: innate host responses to bacterial modification of lipid a structure. J Dent Res 2005;84:584-595.

19. Anderson AC, Al-Ahmad A, Elamin F, Jonas D, Mirghani Y, Schilhabel $\mathrm{M}$, et al.. Comparison of the bacterial composition and structure in symptomatic and asymptomatic endodontic infections associated with root-filled teeth using pyrosequencing. PLoS One 2013;8:e84960.

20. Siqueira JF, Rôças IN. Polymerase chain reaction-based analysis of microorganisms associated with failed endodontic treatment. Oral Surg Oral Med Oral Pathol Oral Radiol Endod 2004;97:85-94.

21. Zhang S, Wang QQ, Zhang CF, Soo I. Identification of dominant pathogens in periapical lesions associated with persistent apical periodontitis. Chin J Dent Res 2010;13:115-121.

22. Van Winkelhoff AJ, Van Steenbergen TJ, Graaff J. Porphyromonas (Bacteroides) endodontalis: its role in endodontal infections. J Endod 1992;18:431-434.

23. Martinho FC, Chiesa WM, Zaia AA, Ferraz CC, Almeida JF, Souza-Filho $\mathrm{FJ}$, et al.. Comparison of endotoxin levels in previous studies on primary endodontic infections. J Endod 2011;37:163-167.

24. Pezelj-Ribaric S, Magasic K, Prpic J, Miletiç I, Karloviç Z. Tumor necrosis factor-alpha in periapical tissue exudates of teeth with apical periodontitis. Mediators Inflamm 2007:69416. doi: 10.1155/2007/69416.

25. Kang BS, Park YG, Cho JY, Kim JK, Lee TK, Kim DW, et al.. Interleukin-1 and tumor necrosis factor-alpha induce collagenolysis and bone resorption by regulation of matrix metalloproteinase- 2 in mouse calvarial bone cells. Immunopharmacol Immunotoxicol 2003;25:347364. 